\title{
Effects of exogenous melatonin on plant growth, root hormones and photosynthetic characteristics of trifoliate orange subjected to salt stress
}

\section{Ceng-hong Hu}

Yangtze University

\section{Ying Zheng}

Yangtze University

Rong-hui Sun

Yangtze University

Jian-hao Zheng

Yangtze University

Mei Li

Yangtze University

dejian zhang ( $\nabla$ zhangdejian0553@126.com )

Yangtze University https://orcid.org/0000-0002-4294-0178

\section{Research Article}

Keywords: hormones, melatonin, photosynthetic, salt stress, trifoliate orange

Posted Date: October 25th, 2021

DOI: https://doi.org/10.21203/rs.3.rs-1008964/v1

License: (1) This work is licensed under a Creative Commons Attribution 4.0 International License.

Read Full License

Version of Record: A version of this preprint was published at Plant Growth Regulation on April 8th, 2022. See the published version at https://doi.org/10.1007/s10725-022-00814-z. 


\section{Abstract}

Soil salinity has negative effects on crop growth and production, and melatonin (MT) plays an important role in regulating the salt stress of plants. However, it is not clear whether exogenous melatonin mitigates the negative effect on citrus plants subjected to salt stress. This study was to explore the response of exogenous melatonin $(0,50,100,150 \mu \mathrm{mol} / \mathrm{L})$ on plant growth, root hormone levels and photosynthetic system of trifoliate orange (Poncirus trifoliata) seedlings exposed to $0,150 \mathrm{mmol} / \mathrm{L} \mathrm{NaCl}$ for 4 weeks. The $150 \mathrm{mmol} / \mathrm{L} \mathrm{NaCl}$ treatment significantly increased root zeatin riboside and gibberellin levels, while dramatically inhibited plant height, root auxin level, leaf photosynthesis and fluorescence indexes of seedlings. However, melatonin seedlings represented greater growth performance and dry matter quality under non-salt and salt stress. Furthermore, the effects of $\mathrm{NaCl}$ stress on the net photosynthetic rate, stomatal conductance, maximum photochemical efficiency, PSII effective photon yied, photochemical quenching and other indicators of seedlings leaves were effectively alleviated and the damage of $\mathrm{NaCl}$ stress was also reduced when seedlings were treated with melatonin. It suggests that exogenous melatonin had positive effects on enhancing salt tolerance of trifoliate orange seedlings, which is involved in greater plant growth, higher auxin level, and stronger photosynthetic physiology, and 100 $\mu \mathrm{mol} / \mathrm{L}$ melatonin concentration has the best result.

\section{Introduction}

Salt stress, one of the important abiotic stresses in plants kingdom, considerably seriously restricts the normal growth of crops (Stassinos et al. 2021). $\mathrm{Cl}^{-}$and $\mathrm{CO}_{3}{ }^{2-}$ ions are the main factors of soil salinization, which seriously restricts agricultural development in arid areas (Wang et al. 2019). Salinealkali soil is not conducive to the growth and development of crops, so that crop tissue is damaged, resulting in physiological drought of crops (Zhou et al. 2021). The salt in the soil will make the seeds of crops mouldy and not germinate in the soil (Zhou et al. 2021). Too much salt will cause the root of crops to rot until dehydration and finally death (Sowmyalakshmi et al. 2015). Salt stress significantly inhibited the growth and dry matter accumulation of plants, resulting in slow plant growth, decreased leaf area and photosynthetic parameters (He et al. 2005). There are 2 reasons about salt stress inhibit the photosynthesis of plants. On the one hand, the toxic effect of inorganic salt ions inhibited the activity of photosynthetic pigments; on the other hand, excessive inorganic salt ions affected the osmotic potential of plant cells and further affected the photosynthetic rate (Lu et al. 2003). Salt stress will cause the decrease of net photosynthetic rate and organic compound synthesis of plants, and eventually affect the normal growth of plants (Lu et al. 2003). Preliminary studies have shown that the increased stomatal resistance resulted in the decreased photosynthetic rate of plants under salt stress (Ennahli and Earl 2005). In addition, another important factor in response to salt damage is hormones (Mahmud et al. 2016). The mechanism of hormones in regulating the salt responses can be divided into two groups, namely, positive-related hormones (e.g., auxin- IAA, gibberellins- GAs, brassinosteroids- BRs and cytokinins- CKs) and stressed hormones (e.g., salicylic acid-SA, jasmonic acid- JA and abscisic acidABA) (Kosová et al. 2012). 
Melatonin (MT) was first discovered in 1995 as an indoles compound, which is a natural phytohormone that occurs in most plants (Dubbels et al. 1995; Sun et al. 2020). In plants, melatonin can increase leaf chlorophyll, regulate the photoperiod of plants and then improve the tolerance of plants under abiotic and biotic stresses which similar to auxin (Tan et al. 2012; Janas and Posmyk 2013; Sun et al. 2020). As a new member of phytohormones, melatonin alleviates the damage of plant stress by regulating the gene transcription level of antioxidant enzymes (Tan et al. 2000; Chen et al. 2018). It is found that both the synthesis of melatonin in plants and the exogenous application of melatonin can effectively improve the adaptability of plants to various stresses (Tan et al. 2000; Chen et al. 2018). Earlier studies found that the appropriate concentration of melatonin can enhance the stress resistance of plants and improve its germination rate, regulate the flowering period, delay the aging of leaves, promote the formation of roots and lateral roots (Pill 1995; Tiryaki and Keles 2012; Park and Back 2012; Byeon and Back 2014; Liang et al. 2018). In cucumber, melatonin can improve germination rate and root resistance ability under drought stress while at the seedling stage, melatonin also inhibited the adverse effects of drought stress by increasing the photosynthetic rate of leaves and increasing the accumulation of chlorophyll content (Zhang et al. 2003; Wang et al. 2016). In tomato, melatonin can significantly increase the chlorophyll in seedlings under salt stress (Sun et al. 2020). Application of exogenous melatonin on grape can significantly alleviate the damage of water-deficient stress, which the mechanism may be ascribed to the enhanced activity of antioxidant enzymes, increased levels of nonenzymatic antioxidants, and increased amount of osmoprotectants (Meng et al. 2015). Melatonin also can significantly increase the content of potassium ion and decrease the content of sodium ion, and then maintain the stability of ion in maize seedlings under salt stress (Jiang et al. 2016). Therefore, previous studies have shown that melatonin can enhance the stress resistance in plants.

Citrus, as an important economic crop, is widely cultivated around the world (Wu et al. 2010a; Zhang et al. 2016; He et al. 2019). Also, citrus plants are one of salt- sensitive horticultural crops (Wu and Zou 2009; Wu et al. 2010b; Wu and Zou 2013; Zhang et al. 2017). In this background, the purpose of the present study was conducted to evaluate melatonin effects on plant growth, root hormone levels, and photosynthetic physiology of trifoliate orange (Poncirus trifoliata L. Raf., a citrus rootstock) under salt stress. The physiological mechanism of alleviating citrus salt stress by exogenous melatonin was discussed fully.

\section{Materials And Methods}

\section{Experimental design}

The experiment was arranged in a $2^{2}$ factorial completely randomized blocked design: soil with or without $\mathrm{NaCl}(150 \mathrm{mmol} / \mathrm{L})$ and 4 concentrations of melatonin (MT, N-acetyl-5-methoxytryptamine, Sigma, USA; MT: 0, 50, 100, $150 \mu \mathrm{mol} / \mathrm{L})$. So there were 8 treatments: $0 \mathrm{mmol} / \mathrm{L} \mathrm{NaCl}+0 \mu \mathrm{mol} / \mathrm{L} \mathrm{MT}, 0$ $\mathrm{mmol} / \mathrm{L} \mathrm{NaCl}+50 \mu \mathrm{mol} / \mathrm{L} \mathrm{MT}, 0 \mathrm{mmol} / \mathrm{L} \mathrm{NaCl}+100 \mu \mathrm{mol} / \mathrm{L} \mathrm{MT}, 0 \mathrm{mmol} / \mathrm{L} \mathrm{NaCl}+150 \mu \mathrm{mol} / \mathrm{L} \mathrm{MT}, 150$ $\mathrm{mmol} / \mathrm{L} \mathrm{NaCl}+0 \mu \mathrm{mol} / \mathrm{L} \mathrm{MT}, 150 \mathrm{mmol} / \mathrm{L} \mathrm{NaCl}+50 \mu \mathrm{mol} / \mathrm{L} \mathrm{MT}, 150 \mathrm{mmol} / \mathrm{L} \mathrm{NaCl}+100 \mu \mathrm{mol} / \mathrm{L} \mathrm{MT}, 150$ 
$\mathrm{mmol} / \mathrm{L} \mathrm{NaCl}+150 \mu \mathrm{mol} / \mathrm{L} \mathrm{MT}$. Each treatment was replicated 6 times, and each replicate had 3 seedlings, for a total of 144 seedlings.

\section{Plant culture}

The 5-leaf-old trifoliate orange seedlings were transplanted into $2.0 \mathrm{~L}$ pots containing autoclaved $(0.11$ $\mathrm{MPa}, 121^{\circ} \mathrm{C}, 1.5 \mathrm{~h}$ ) substrates (soil : sand $=3: 1, \mathrm{v} / \mathrm{v}$ ). After two weeks of transplanted, salt and melatonin treatments were applied. The designed $\mathrm{NaCl}$ and $\mathrm{MT}$ solutions were weekly watered into each pot. Such salt and melatonin treatments were maintained for four weeks until the plants were harvested. These seedlings were grown in a glasshouse of Yangtze University campus between March to May, 2021.

\section{Variable determinations}

At harvesting, plant height and stem diameter were determined by a ruler. The whole seedlings were divided into the roots and the shoots for gain the data of total dry weight, root dry shoot and shoot dry weight.

chlorophyll content, including chlorophyll a (Chla), chlorophyll b (Chlb) and total chlorophyll content (Chla+Chlb), were determined for absorbance at wavelength of 665,649 and $470 \mathrm{~nm}$ by spectrophotometer (UH5300, Hitachi of Japan).

Leaf photosynthetic characteristics, including net photosynthetic rate (Pn), stomatal conductance (Gs), intercellular $\mathrm{CO}_{2}$ concentration $(\mathrm{Ci})$ and transpiration rate $(\mathrm{Tr})$, were determined by portable photosynthetic system analyzer (Li-6400, Li-Cor of USA).

Leaf chlorophyll fluorescence kinetic parameters, including PSIl reaction center actual photochemical efficiency ( $(P S I I), P S I l$ effective light quantum yield $\left(F v^{\prime} / F m\right)$, photochemical quenching coefficient (qP) and non-photochemical quenching coefficient (NPQ), were determined by luminoscope (Handy-PEA, Lufthansa of England) based on the protocol of Baker et al. (2008).

Root endogenous hormones, including indole acetic acid (IAA), zeatin riboside (ZR), gibberellin (GAs) and brassinolide (BRs), were extracted by the protocol of He et al. (2019) and were determined by liquid chromatography-mass spectrometry (LC-MS) based on the protocol of Kojima and Sakakibar (2012).

\section{Statistical analysis}

The data were statistically analyzed according to the variance (ANOVA) (SAS software 8.1v), and the significant difference between the treatments was compared with the Duncan's multiple range tests at $P<$ 0.05 .

\section{Results}

\section{Plant growth performance}


As shown in Table 1, salt stress had suppressed trifoliate orange seedlings' growth observably. Plant height, stem diameter, total dry weight, shoot and root dry weight were significantly decreased in the salt treatments compared to the non-salt treatments, irrespective of MT status (Table 1). 4 concentrations of MT treated seedlings showed better growth performance, especially the $100 \mu \mathrm{mol} / \mathrm{L}$ MT. Treated with 100 $\mu \mathrm{mol} / \mathrm{L}$ MT conferred significantly increased plant height, stem diameter, total plant dry weight, root and soot dry weight by $5.5 \%, 2.5 \%, 4.5 \%, 5.0 \%$ and $2.5 \%$ under non-salt stress and by $21.75 \%, 27.8 \%, 11.9 \%$, $11.9 \%$ and $14.7 \%$ under salt stress (Table 1). Therefore, the damage of salt stress on plant growth was reduced when seedlings were treated with melatonin.

Table 1

Effects of exgenous melayonin (MT) on plant growth performance of trifoliate orange seedlings under non-salt $(0 \mathrm{mmol} / \mathrm{L})$ and salt stress $(150 \mathrm{mmol} / \mathrm{L})$ conditions.

\begin{tabular}{|c|c|c|c|c|c|c|}
\hline \multicolumn{2}{|c|}{ Treatments } & \multirow{2}{*}{$\begin{array}{l}\text { Plant height } \\
\text { (cm) }\end{array}$} & \multirow{2}{*}{$\begin{array}{l}\begin{array}{l}\text { Stem } \\
\text { diameter } \\
(\mathrm{mm})\end{array} \\
2.81 \pm 0.15 \mathrm{a}\end{array}$} & \multirow{2}{*}{$\begin{array}{l}\begin{array}{l}\text { Totol dry } \\
\text { weight }(\mathrm{g})\end{array} \\
2.01 \pm 0.12 \mathrm{a}\end{array}$} & \multirow{2}{*}{$\begin{array}{l}\begin{array}{l}\text { Root dry } \\
\text { weight (g) }\end{array} \\
0.80 \pm 0.02 a\end{array}$} & \multirow{2}{*}{$\begin{array}{l}\text { Shoot dry } \\
\text { weight (g) }\end{array}$} \\
\hline $\begin{array}{l}0 \\
\mathrm{mmol} / \mathrm{L} \\
\mathrm{NaCl}\end{array}$ & $\begin{array}{l}0 \\
\mu \mathrm{mol} / \mathrm{L} \\
\mathrm{MT}\end{array}$ & & & & & \\
\hline & $\begin{array}{l}50 \\
\mu \mathrm{mol} / \mathrm{L} \\
\mathrm{MT}\end{array}$ & $26.25 \pm 1.59 a b$ & $2.82 \pm 0.16 a$ & $2.08 \pm 0.11 a$ & $0.83 \pm 0.02 a$ & $1.24 \pm 0.09 a$ \\
\hline & $\begin{array}{l}100 \\
\mu \mathrm{mol} / \mathrm{L} \\
\text { MT }\end{array}$ & $26.51 \pm 1.34 a$ & $2.88 \pm 0.17 a$ & $2.10 \pm 0.19 a$ & $0.84 \pm 0.03 a$ & $1.25 \pm 0.11 \mathrm{a}$ \\
\hline & $\begin{array}{l}150 \\
\mu \mathrm{mol} / \mathrm{L} \\
\text { MT }\end{array}$ & $26.12 \pm 1.98 a b$ & $2.81 \pm 0.12 a$ & $2.07 \pm 0.13 a$ & $0.83 \pm 0.02 a$ & $1.23 \pm 0.12 \mathrm{a}$ \\
\hline \multirow[t]{4}{*}{$\begin{array}{l}150 \\
\mathrm{mmol} / \mathrm{L} \\
\mathrm{NaCl}\end{array}$} & $\begin{array}{l}0 \\
\mu \mathrm{mol} / \mathrm{L} \\
\mathrm{MT}\end{array}$ & $20.01 \pm 1.01 d$ & $2.52 \pm 0.10 \mathrm{~b}$ & $1.68 \pm 0.09 c$ & $0.67 \pm 0.01 c$ & $1.02 \pm 0.07 c$ \\
\hline & $\begin{array}{l}50 \\
\mu \mathrm{mol} / \mathrm{L} \\
\mathrm{MT}\end{array}$ & $23.95 \pm 1.36 c$ & $2.55 \pm 0.12 b$ & $1.79 \pm 0.08 b c$ & $0.72 \pm 0.02 b c$ & $1.06 \pm 0.08 \mathrm{bc}$ \\
\hline & $\begin{array}{l}100 \\
\mu \mathrm{mol} / \mathrm{L} \\
\mathrm{MT}\end{array}$ & $24.35 \pm 1.79 b c$ & $2.59 \pm 0.15 b$ & $1.88 \pm 0.07 b$ & $0.75 \pm 0.03 b$ & $1.17 \pm 0.11 b$ \\
\hline & $\begin{array}{l}150 \\
\mu \mathrm{mol} / \mathrm{L} \\
\mathrm{MT}\end{array}$ & $23.76 \pm 1.47 \mathrm{c}$ & $2.56 \pm 0.14 b$ & $1.77 \pm 0.06 \mathrm{bc}$ & $0.71 \pm 0.01 b c$ & $1.08 \pm 0.06 b c$ \\
\hline
\end{tabular}

\section{Leaf photosynthetic pigment content}

Salt stress significantly decreased leaf photosynthesis pigment indexes of seedlings. Compared to the non-salt treatments, $\mathrm{NaCl}$ significantly decreased the levels of chlorophyll a (Chla), chlorophyll b (Chlb) 
and total chlorophyll content (Chla+Chlb), irrespective of MT status (Table 2). The MT treatments, especially the $100 \mu \mathrm{mol} / \mathrm{L} \mathrm{MT}$, significantly increased leaf Chla, Chlb, Chla+Chlb by $5.3 \%, 8.9 \%$, and $8.3 \%$ under non-salt stress and by $59.0 \%, 35.4 \%$, and $55.4 \%$ under salt stress (Table 2 ). However, there had no significant difference of Chla/Chlb in all treatments, irrespective of salt stress and MT (Table 2). Hence, the damage of salt stress on leaf photosynthesis pigment was reduced when seedlings were treated with melatonin.

Table 2

Effects of exgenous melayonin (MT) on photosynthetic pigment content in leaves of trifoliate orange seedlings under non-salt $(0 \mathrm{mmol} / \mathrm{L})$ and salt stress $(150 \mathrm{mmol} / \mathrm{L})$ conditions.

\begin{tabular}{|c|c|c|c|c|c|}
\hline Treatments & & Chla (mg/g) & Chlb (mg/g) & $\begin{array}{l}\text { Chla+Chlb } \\
(\mathrm{mg} / \mathrm{g})\end{array}$ & Chla/Chlb \\
\hline \multirow[t]{4}{*}{$0 \mathrm{mmol} / \mathrm{L} \mathrm{NaCl}$} & $0 \mu \mathrm{mol} / \mathrm{L} \mathrm{MT}$ & $1.72 \pm 0.16 a b$ & $0.72 \pm 0.05 a b$ & $2.41 \pm 0.12 b$ & $2.28 \pm 0.12 \mathrm{a}$ \\
\hline & $50 \mu \mathrm{mol} / \mathrm{L} \mathrm{MT}$ & $1.79 \pm 0.11 \mathrm{a}$ & $0.75 \pm 0.06 a$ & $2.51 \pm 0.11 \mathrm{ab}$ & $2.38 \pm 0.20 a$ \\
\hline & $\begin{array}{l}100 \mu \mathrm{mol} / \mathrm{L} \\
\mathrm{MT}\end{array}$ & $1.81 \pm 0.14 a$ & $0.79 \pm 0.07 a$ & $2.61 \pm 0.19 a$ & $2.27 \pm 0.13 a$ \\
\hline & $\begin{array}{l}150 \mu \mathrm{mol} / \mathrm{L} \\
\mathrm{MT}\end{array}$ & $1.73 \pm 0.12 \mathrm{ab}$ & $0.76 \pm 0.02 a$ & $2.47 \pm 0.13 a b$ & $2.29 \pm 0.17 a$ \\
\hline \multirow{4}{*}{$\begin{array}{l}150 \mathrm{mmol} / \mathrm{L} \\
\mathrm{NaCl}\end{array}$} & $0 \mu \mathrm{mol} / \mathrm{L} \mathrm{MT}$ & $1.05 \pm 0.05 d$ & $0.48 \pm 0.03 c$ & $1.48 \pm 0.09 d$ & $2.26 \pm 0.14 a$ \\
\hline & $50 \mu \mathrm{mol} / \mathrm{LMT}$ & $1.22 \pm 0.06 \mathrm{c}$ & $0.56 \pm 0.04 \mathrm{bc}$ & $1.88 \pm 0.08 c$ & $2.27 \pm 0.16 \mathrm{a}$ \\
\hline & $\begin{array}{l}100 \mu \mathrm{mol} / \mathrm{L} \\
\mathrm{MT}\end{array}$ & $1.67 \pm 0.09 b$ & $0.65 \pm 0.03 b$ & $2.30 \pm 0.07 b$ & $2.40 \pm 0.21 a$ \\
\hline & $\begin{array}{l}150 \mu \mathrm{mol} / \mathrm{L} \\
\mathrm{MT}\end{array}$ & $1.23 \pm 0.07 \mathrm{c}$ & $0.57 \pm 0.05 b c$ & $1.83 \pm 0.11 \mathrm{c}$ & $2.19 \pm 0.11 a$ \\
\hline
\end{tabular}

\section{Leaf photosynthetic parameters}

As shown in Table 3, salt stress significantly decreased leaf photosynthetic parameters of seedlings. Compared to the non-salt treatment, $150 \mathrm{mmol} / \mathrm{L} \mathrm{NaCl}$ dramatically decreased the levels of net photosynthetic rate $(\mathrm{Pn})$, stomatal conductance $(\mathrm{Gs})$, intercellular $\mathrm{CO}_{2}$ concentration (Ci) and transpiration rate $(\mathrm{Tr}$ ) by $26.3 \%, 49.2 \%, 40.0 \%$ and $29.6 \%$ (Table 3 ). Although, MT treatment had not significant effects on Pn, Gs, Ci and Tr under non-salt stress. However, $100 \mu \mathrm{mol} / \mathrm{L}$ MT notably increased Pn, Gs, Ci and Tr by $22.9 \%, 72.8 \%, 57.3 \%$ and $24.4 \%$ under salt stress (Table 3). So, the decrease of salt stress on leaf photosynthesis was partially promoted when seedlings were treated with melatonin. 
Table 3

Effects of exgenous melayonin (MT) on photosynthetic parameters of trifoliate orange seedlings leaves under non-salt $(0 \mathrm{mmol} / \mathrm{L})$ and salt stress $(150 \mathrm{mmol} / \mathrm{L})$ conditions.

\begin{tabular}{|c|c|c|c|c|c|}
\hline Treatments & & $\begin{array}{l}\mathrm{Pn} \\
\left(\mu \mathrm{mol} / \mathrm{m}^{2} . \mathrm{s}\right)\end{array}$ & $\begin{array}{l}\text { Gs } \\
\left(\mu \mathrm{mol} / \mathrm{m}^{2} . s\right)\end{array}$ & $\mathrm{Ci}(\mu \mathrm{mol} / \mathrm{mol})$ & $\begin{array}{l}\operatorname{Tr} \\
\left(\mathrm{mmol} / \mathrm{m}^{2} . \mathrm{s}\right)\end{array}$ \\
\hline \multirow[t]{4}{*}{$\begin{array}{l}0 \mathrm{mmol} / \mathrm{L} \\
\mathrm{NaCl}\end{array}$} & $\begin{array}{l}0 \mu \mathrm{mol} / \mathrm{L} \\
\text { MT }\end{array}$ & $8.15 \pm 0.76 \mathrm{ab}$ & $1.81 \pm 0.12 \mathrm{a}$ & $200.01 \pm 10.19 a b$ & $2.80 \pm 0.15 a$ \\
\hline & $\begin{array}{l}50 \mu \mathrm{mol} / \mathrm{L} \\
\mathrm{MT}\end{array}$ & $8.24 \pm 0.59 a$ & $1.82 \pm 0.13 a$ & $210.08 \pm 20.15 a$ & $2.83 \pm 0.19 a$ \\
\hline & $\begin{array}{l}100 \mu \mathrm{mol} / \mathrm{L} \\
\text { MT }\end{array}$ & $8.50 \pm 0.34 a$ & $1.82 \pm 0.10 \mathrm{a}$ & $212.10 \pm 18.10 a$ & $2.84 \pm 0.22 \mathrm{a}$ \\
\hline & $\begin{array}{l}150 \mu \mathrm{mol} / \mathrm{L} \\
\text { MT }\end{array}$ & $8.19 \pm 0.46 a b$ & $1.81 \pm 0.16 a$ & $209.07 \pm 19.17 a$ & $2.83 \pm 0.26 a$ \\
\hline \multirow[t]{4}{*}{$\begin{array}{l}150 \mathrm{mmol} / \mathrm{L} \\
\mathrm{NaCl}\end{array}$} & $\begin{array}{l}0 \mu \mathrm{mol} / \mathrm{L} \\
\mathrm{MT}\end{array}$ & $6.01 \pm 0.41 c$ & $0.92 \pm 0.07 c$ & $120.68 \pm 11.99 c$ & $1.97 \pm 0.11 \mathrm{c}$ \\
\hline & $\begin{array}{l}50 \mu \mathrm{mol} / \mathrm{L} \\
\mathrm{MT}\end{array}$ & $6.96 \pm 0.39 b c$ & $1.55 \pm 0.12 b$ & $169.79 \pm 15.58 \mathrm{bc}$ & $2.22 \pm 0.12 b c$ \\
\hline & $\begin{array}{l}100 \mu \mathrm{mol} / \mathrm{L} \\
\text { MT }\end{array}$ & $7.39 \pm 0.63 b$ & $1.59 \pm 0.11 b$ & $189.88 \pm 16.07 \mathrm{~b}$ & $2.45 \pm 0.21 b$ \\
\hline & $\begin{array}{l}150 \mu \mathrm{mol} / \mathrm{L} \\
\mathrm{MT}\end{array}$ & $6.77 \pm 0.41 b c$ & $1.00 \pm 0.04 c$ & $168.77 \pm 14.09 b c$ & $2.21 \pm 0.19 b c$ \\
\hline
\end{tabular}

Note: $\mathrm{Pn}$ - net photosynthetic rate, Gs- stomatal conductance, $\mathrm{Ci}$ - intercellular $\mathrm{CO}_{2}$ concentration and Tr- transpiration rate.

\section{Leaf fluorescence parameters}

Salt stress changes leaf fluorescence parameters of seedlings. Compared to the non-salt treatments, 150 $\mathrm{mmol} / \mathrm{L} \mathrm{NaCl}$ significantly decreased the levels of PSIl reaction center actual photochemical efficiency $(\varphi \mathrm{PSII}), \mathrm{PSIl}$ effective light quantum yield $\left(F v^{\prime} / F m\right)$ and photochemical quenching coefficient (qP) by $27.4 \%, 28.1 \%$ and $25.3 \%$ (Table 4). Although, MT treatment had not significant effects on $\varphi P S I I, F v^{\prime} / F m^{\prime}$ and $\mathrm{qP}$ under non-salt stress. However, under salt stress, 3 concentrations of MT notably increased $\varphi P S I I$, $F v^{\prime} / F m^{\prime}$ and $\mathrm{qP}$ by $22.2 \%, 31.1 \%, 24.4 \%$, and $12.9 \%, 25.8 \%, 14.5 \%$, and $16.2 \%, 25.0 \%, 16.2 \%$, respectively (Table 4). However, the level of non-photochemical quenching coefficient (NPQ) was significantly increased by $161.7 \%$ on salt stress, compared with non-salt stress (Table 4). And, MT reduced NPQ to varying degrees, irrespective of salt status. In consequence, the damage of salt stress on leaf fluorescence parameters was partially restored when seedlings were treated with melatonin. 
Table 4

Effects of exgenous melayonin (MT) on leaf fluorescence parameters of trifoliate orange seedlings under non-salt $(0 \mathrm{mmol} / \mathrm{L})$ and salt stress $(150 \mathrm{mmol} / \mathrm{L})$ conditions.

\begin{tabular}{|c|c|c|c|c|c|}
\hline Treatments & & $\varphi P S I I$ & $F v^{\prime} / F m^{\prime}$ & $\mathrm{qP}$ & NPQ \\
\hline \multirow[t]{4}{*}{$0 \mathrm{mmol} / \mathrm{L} \mathrm{NaCl}$} & $0 \mu \mathrm{mol} / \mathrm{L} \mathrm{MT}$ & $0.62 \pm 0.06 a$ & $0.85 \pm 0.05 a$ & $0.91 \pm 0.02 a$ & $0.60 \pm 0.04 d$ \\
\hline & $50 \mu \mathrm{mol} / \mathrm{L} \mathrm{MT}$ & $0.63 \pm 0.05 a$ & $0.86 \pm 0.06 a$ & $0.92 \pm 0.03 a$ & $0.59 \pm 0.05 d$ \\
\hline & $100 \mu \mathrm{mol} / \mathrm{L} \mathrm{MT}$ & $0.66 \pm 0.04 a$ & $0.88 \pm 0.07 a$ & $0.93 \pm 0.09 a$ & $0.58 \pm 0.03 d$ \\
\hline & $150 \mu \mathrm{mol} / \mathrm{L} \mathrm{MT}$ & $0.63 \pm 0.05 a$ & $0.81 \pm 0.05 a$ & $0.91 \pm 0.03 a$ & $0.60 \pm 0.05 d$ \\
\hline \multirow[t]{4}{*}{$150 \mathrm{mmol} / \mathrm{L} \mathrm{NaCl}$} & $0 \mu \mathrm{mol} / \mathrm{L} \mathrm{MT}$ & $0.45 \pm 0.03 c$ & $0.62 \pm 0.02 c$ & $0.68 \pm 0.05 c$ & $1.57 \pm 0.13 a$ \\
\hline & $50 \mu \mathrm{mol} / \mathrm{L} \mathrm{MT}$ & $0.55 \pm 0.04 b$ & $0.70 \pm 0.04 b$ & $0.79 \pm 0.06 b$ & $1.22 \pm 0.12 b$ \\
\hline & $100 \mu \mathrm{mol} / \mathrm{L} \mathrm{MT}$ & $0.59 \pm 0.03 a b$ & $0.78 \pm 0.05 a b$ & $0.85 \pm 0.07 a b$ & $1.05 \pm 0.09 c$ \\
\hline & $150 \mu \mathrm{mol} / \mathrm{L}$ MT & $0.56 \pm 0.01 \mathrm{~b}$ & $0.71 \pm 0.02 b$ & $0.79 \pm 0.05 b$ & $1.21 \pm 0.11 b$ \\
\hline
\end{tabular}

\section{Root endogenous hormones}

The trifoliate orange seedlings roots have been harvested for measuring the levels of phytohormones, such as indoleacetic acid (IAA), zeatin riboside (ZR), gibberellin (GAs) and Brassinolide (BRs). Compared with non-salt seedlings, salt stress seedlings had significantly lower level of IAA (Table 5). By contrast, salt stress observably increased the levels of ZR and GAs by $29.4 \%$ and $44.4 \%$ (Table 5). However, there has no difference of BRs concentration between non-salt and salt treatments. With regards to MT, its treatments increased root IAA level under non-salt and salt stress conditions in varying degrees, of which $100 \mu \mathrm{mol} / \mathrm{L}$ MT has the best result (Table 5). However, MT had not significant effects on root ZR, GAs and BRs of trifoliate orange seedlings, irrespective of non-salt and salt stress (Table 5). 
Table 5

Effects of exgenous melayonin (MT) on concentrations of root endogenous hormones of trifoliate orange seedlings under non-salt $(0 \mathrm{mmol} / \mathrm{L})$ and salt stress $(150 \mathrm{mmol} / \mathrm{L})$ conditions.

\begin{tabular}{|c|c|c|c|c|c|}
\hline Treatments & & $\begin{array}{l}\text { IAA (ng/g } \\
\text { FW) }\end{array}$ & $\begin{array}{l}\mathrm{ZR}(\mathrm{ng} / \mathrm{g} \\
\mathrm{FW})\end{array}$ & $\begin{array}{l}\text { GAs (ng/g } \\
\text { FW) }\end{array}$ & $\begin{array}{l}\text { BRs (ng/g } \\
\text { FW) }\end{array}$ \\
\hline \multirow[t]{4}{*}{$0 \mathrm{mmol} / \mathrm{L} \mathrm{NaCl}$} & $0 \mu \mathrm{mol} / \mathrm{L} \mathrm{MT}$ & $60.13 \pm 1.26 a b$ & $5.81 \pm 0.15 b$ & $6.01 \pm 0.12 b$ & $6.80 \pm 0.02 a$ \\
\hline & $50 \mu \mathrm{mol} / \mathrm{L} M T$ & $61.25 \pm 1.59 a b$ & $5.82 \pm 0.16 b$ & $6.08 \pm 0.11 b$ & $6.83 \pm 0.02 a$ \\
\hline & $\begin{array}{l}100 \mu \mathrm{mol} / \mathrm{L} \\
\mathrm{MT}\end{array}$ & $66.51 \pm 1.34 a$ & $5.80 \pm 0.17 \mathrm{~b}$ & $6.10 \pm 0.19 b$ & $6.88 \pm 0.03 a$ \\
\hline & $\begin{array}{l}150 \mu \mathrm{mol} / \mathrm{L} \\
\text { MT }\end{array}$ & $66.12 \pm 1.98 a$ & $5.81 \pm 0.12 b$ & $6.07 \pm 0.13 b$ & $6.83 \pm 0.02 a$ \\
\hline \multirow{4}{*}{$\begin{array}{l}150 \mathrm{mmol} / \mathrm{L} \\
\mathrm{NaCl}\end{array}$} & $0 \mu \mathrm{mol} / \mathrm{L} \mathrm{MT}$ & $50.01 \pm 1.01 c$ & $7.52 \pm 0.10 a$ & $8.68 \pm 0.09 a$ & $6.97 \pm 0.01 a$ \\
\hline & $50 \mu \mathrm{mol} / \mathrm{L} M T$ & $52.95 \pm 1.36 b c$ & $7.53 \pm 0.12 \mathrm{a}$ & $8.59 \pm 0.08 a$ & $7.02 \pm 0.02 a$ \\
\hline & $\begin{array}{l}100 \mu \mathrm{mol} / \mathrm{L} \\
\mathrm{MT}\end{array}$ & $55.35 \pm 1.79 b$ & $7.52 \pm 0.15 a$ & $8.88 \pm 0.07 a$ & $7.11 \pm 0.03 a$ \\
\hline & $\begin{array}{l}150 \mu \mathrm{mol} / \mathrm{L} \\
\mathrm{MT}\end{array}$ & $52.76 \pm 1.47 b c$ & $7.51 \pm 0.14 a$ & $8.57 \pm 0.06 a$ & $7.01 \pm 0.01 a$ \\
\hline
\end{tabular}

\section{Discussion}

Salt stress is one of the most problematic abiotic stress affecting plants in agriculture worldwide. In saline soils, plants try to neutralize the effects of salt stress by physiological changes, leading to the decreasing of both oxidative and osmotic stresses (Stassinos et al. 2021). Melatonin, an indoleamine widely found in animals and plants, is considered as a candidate phytohormone that affects responses to a variety of biotic and abiotic stresses, such as salt stress (Wei et al. 2015; Li et al. 2019). In the present study, exogenous melatonin treatment alleviated the inhibition of trifoliate orange seedling growth under $150 \mathrm{mmol} / \mathrm{L} \mathrm{NaCl}$ stress to a certain extent, which is in line with the earlier result as reported by Zhang et al. (2014) that melatonin treatment could improve the germination ability of Pennisetum alopecuroides (Linn.) seeds and alleviate the negative effect of salt stress on its growth. In addition, exogenous melatonin treatment can effectively promote dry matter accumulation, leaf elongation rate and alleviate the inhibition of plant height under salt stress, which imply that melatonin improved plant resistance to salt stress through osmotic regulation (Li et al. 2019). Also, melatonin promotes soybean growth, seed production, and stresses (salt and drought) tolerance by regulating cell division, photosynthesis, carbohydrate metabolism, fatty acid biosynthesis, and ascorbate metabolism (Wei et al. 2015).

When plants are under stress, the photosynthetic rate and the level of chlorophyll of leaves were decreases (Harizanova and Koleva-Valkova, 2019). The main medium of plant photosynthesis is leaf, 
and the amount of chlorophyll content directly affects the ability of plant to carry out photosynthesis (Demming and Adams, 1996). Salt stress not only affect the synthesis of chlorophyll but also accelerate the decomposition of chlorophyll, resulting in the decrease of chlorophyll content (Schreiber et al. 1998). Our results showed that $\mathrm{NaCl}$ stress led to the degradation of chlorophyll in leaves, and exogenous melatonin alleviated the damage of $\mathrm{NaCl}$ stress on chlorophyll $\mathrm{A}$ and chlorophyll $\mathrm{B}$ in trifoliate orange leaves, as similarly reported by Kostopoulou et al. (2014) in citurs. Salt stress could also decrease the net photosynthetic rate of plants, reduce the synthesis of organic matter, and ultimately affect the normal growth of plants (Centritto et al. 2003). In cotton, salt stress significantly inhibited the seedlings growth and biomass accumulation, and decreased leaf area and the indexes of Pn, Gs, Ci and Tr, which is in line with our results (He et al. 2005). In this study, salt stress decreased leaf Pn, Gs, $\mathrm{Ci}$ and $\mathrm{Tr}$ while melatonin increased them partially, which is agreement with previous work in cucumber (Harizanova and KolevaValkova, 2019). The possible mechanism is that melatonin can improve the content of chlorophyll, promote the activity of PSII and effectively regulate the photosynthesis of plant leaves under salt stress, resulting in improve the salt tolerance of plants.

Chlorophyll fluorescence is an effective probe of photosynthesis, through which almost all changes of photosynthesis can be detected (Mimuro et al. 1999). Chlorophyll fluorescence contains PSII reaction center actual photochemical efficiency ( $\varphi$ PSII), PSIl effective light quantum yield $\left(F v^{\prime} / F m\right)$, photochemical quenching coefficient (qP) and non-photochemical quenching coefficient (NPQ) (Farzad et al. 2007). This study showed that salt stress markedly increased NPQ while significantly decreased $\varphi P S I I$, $F v^{\prime} / F m^{\prime}$ and $\mathrm{qP}$. Furthermore, melatonin alleviated the increase and decrease degree of them. As actual photochemical efficiency of the PSII reaction center, the decrease of $\varphi P S I I$ indicated that the photosynthetic electron decreased under carbon fixation, resulting in the decrease of net photosynthetic rate, which explained the mechanism of salt stress inhibiting photosynthesis (Han et al. 2010). The decrease of $F v^{\prime} / F m^{\prime}$ is due to the fact that photosynthetic electron transfer is not carried out in time after light capture, but directly consumes light energy through chlorophyll transformation, which leads to the decrease of PSII (Shibata et al. 2012). The index of qP reflects the degree to which the photoreaction center is effectively applied in the photochemical reaction. The decrease of qP indicated that PSII could not transfer photosynthetic electrons smoothly after being damaged, and the effective reaction light decreased (Havaux et al. 1991). NPQ is a non-photochemical quenching index, reflecting the process of chlorophyll absorption and transformation, and is an effective heat dissipation element used to resist light damage (Tietz et al. 2017). In this experiment, $\mathrm{NaCl}$ stress leaded to an increase in NPQ, resulting in a decrease in PSII and photosynthetic rate. Melatonin increased the index of $\varphi \mathrm{PSII}, F v^{\prime} / F m^{\prime}$ and $\mathrm{qP}$ and decrease the NPQ in trifoliate orange seedlings under salt stress, implying that melatonin can effectively improve PSII photochemical efficiency and photosynthetic rate of leaves, which is consistent with previous studies on maize and celery (Ye et al. 2016). Thus, melatonin can improve the photosynthetic capacity of plants under $\mathrm{NaCl}$ stress.

IAA plays an important role in regulating plant growth under adverse stresses (Iqbal and Ashraf, 2007; Zhang et al. 2013, 2018, 2019). As an cytokinin (CTK), ZR has been reported to have the ability to enhance plant salt tolerance and temperature stress (Javid et al. 2011). GAs are an essential for many 
plants in response to abiotic stress and also take part in plant growth and development (Colebrook et al. 2014). BRs, a kind of steroid hormones, are necessary for plant growth and development, and can tolerate environmental stresses by inducing antioxidant activities (Bajguz and Piotrowska-Niczyporuk, 2014). IAA could significantly enhanced the tolerance of salt stress in maize (Kaya et al. 2013). Our study showed that there was a significant decrease in root IAA levels of melatonin and non-melatonin trifoliate orange seedlings under the salt stress versus the non-salt stress. At the same time, melatonin treatment notably increased root IAA concentration. The result is similar to the findings of Liu et al. (2016). Furthermore, IAA is closely related to the growth and development of plant roots (Liu et al. 2018). Therefore, the melatonin effect on IAA is effectively associated with melatonin-induced growth improvement, root modification and salt tolerance. However, the salt stress significantly increased root ZR and GAs levels, while melatonin has no effect with ZR and GAs in this study. Perhaps there has no interaction between melatonin and ZR or GAs. In this study, melatonin did not significantly alter root BRs concentration in non-salt and salt trifoliate orange seedlings. Perhaps in salt stress, the regulation of melatonin to other phytohormones is sufficient for plants to resist salt stress. So, melatonin increased plant salt tolerance mainly through interaction with auxin.

\section{Conclusion}

The salt stress significantly increased root zeatin riboside and gibberellin levels, while dramatically inhibited plant height, root auxin level, leaf photosynthesis and fluorescence indexes of seedlings. However, melatonin seedlings represented greater growth performance and dry matter quality under nonsalt and salt stress. Furthermore, the effects of salt stress on the net photosynthetic rate, stomatal conductance, maximum photochemical efficiency, PSIl effective photon yied, photochemical quenching and other indicators of seedlings leaves were effectively alleviated and the damage of salt stress was also reduced when seedlings were treated with melatonin. Under salt stress, melatonin can promote the growth of trifoliate orange seedlings, significantly increase the content of photosynthetic pigments in seedlings leaves, effectively improve PSII photochemical efficiency and photosynthetic rate of seedlings, and then enhance the salt tolerance of seedlings. Melatonin enhances plant salt toleranc in 2 ways: one is via direct pathways, such as the direct clearance of reactive oxygen species; the other is via an indirect pathway by enhancing photosynthetic efficiency, antioxidant enzyme activity and metabolite content, and by regulating transcription factors associated with salt stress. In addition, many results consider that melatonin probably achieved its promotional roles in plants through enhancement of genes involved in cell division, photosynthesis, phytohormone, carbohydrate metabolism, fatty acid biosynthesis, and ascorbate metabolism. Our results demonstrate that melatonin has significant potential for improvement of plant growth and salt tolerance. Further study should uncover more about the molecular mechanisms of melatonin's function in plant kingdom.

\section{Declarations}

\section{Ethical Statements}


In consideration of the publication, we hereby warrant and undertake:

1. This article is an original work and no portion of the study has been published or is under consideration for publication elsewhere.

2. None of the authors has any potential conflict of interest related to this manuscript.

3. All authors have contributed to the work, and they have agreed to submit the manuscript.

\section{Acknowledgements}

This work was supported by the Young and Middle-aged Talent Project of Hubei Provincial Education Department (grant number Q20181304) and the National Natural Science Foundation of China (No. 32001984).

\section{References}

1. Bajguz A, Piotrowska-Niczyporuk A (2014) Brassinosteroids implicated in growth and stress responses. In: Tran, L.S. and S. Pal (eds.) Phytohormones: A Window to Metabolism, Signaling and Biotechnological Applications. Springer, New York, NY. Pp:163-190

2. Baker NR (2008) Chlorophyll Fluorescence: A Probe of Photosynthesis In Vivo. Ann Rev Plant Bio 59:89-113

3. Byeon Y, Back K (2014) An increase in melatonin in transgenic rice causes pleiotropic phenotypes, including enhanced seedling growth,delayed flowering, and low grain yield. J Pineal Res $56: 408-414$

4. Centritto M, Loreto F, Chartzoulakis K (2003) The use of low [CO2] to estimate diffusional and nondiffusional limitations of photosynthetic capacity of salt-stressed olive saplings. Plant Cell Environ 26:585-594

5. Chen ZP, Gu Q, Yu XL, Huang L, Xu S, Wang R, Shen W, Shen W(2018) Hydrogen peroxide acts downstream of melatonin to induce lateral root formation. Ann Bot 121:1127-1136

6. Colebrook EH, Thomas SG, Phillips AL, Hedden P(2014) The role of gibberellin signalling in plant responses to abiotic stress. J Exp Biol 217:67-75

7. Demming AB, Adams WW(1996) The role of the xanthophyll cycle carotenoids in the protection of photosynthesis. Trends Plant Sci 1:21-26

8. Dubbels R, Reiter RJ, Klenke E, Goebel A, Schnakenberg E, Ehlers C, Schiwara HW, Schloot W(1995). Melatonin in edible plants identified by radioimmunoassay and by high performance liquid chromatography-mass spectrometry. J Pineal Res 18:28-31

9. Ennahli S, Earl HJ (2005) Physiological limitations to photosynthetic carbon assimilation in cotton under water stress. Crop Science, 45:2374-2382 
10. Farzad P, Mohammad N, Moghadam H, Hossein Z, Alahmadi MJ (2007) Effects of drought stress on chlorophyll fluorescence parameters, chlorophyll content and grain yield of wheat cultivars. Journal of Biological Sciences 7:841-847

11. Han B, Chen GX, Gao ZP, Wei XD, Xie KB, Yang XS (2010) The changes of PSIl chlorophyll fluorescence dynamic characteristic during leaf senescence of ginkgo. Acta Horticulturae Sinica 37(2): 171-178

12. Harizanova A, Koleva-Valkova L (2019) Effect of silicon on photosynthetic rate and the chlorophyll fluorescence parameters at hydroponically grown cucumber plants under salinity stress. Journal of Central European Agriculture 20:953-960

13. Havaux M, Strasser RJ, Greppin H(1991) A theoretical and experimental analysis of the $q P$ and qn coefficients of chlorophyll fluorescence quenching and their relation to photochemical and nonphotochemical events. Photosynthesis Research 27:41-55

14. He JD, Li JL, Wu QS (2019) Effects of Rhizoglomus intraradices on plant growth and root endogenous hormones of trifoliate orange under salt stress. Journal of Animal and Plant Sciences 29(7):245-250

15. He C, Yan J, Shen G, Fu L, Holaday AS, Auld D, Zhang H(2005) Expression of an Arabidopsis vacuolar sodium/proton antiporter gene in cotton improves photosynthetic performance under salt conditions and increases fiber yield in the field. Plant and Cell Physiology 46:1848-1854

16. He C, Yan JQ, Shen GX, Fu LH, Holaday AS, Auld D, Blumwald E, Zhang H(2005) Expression of an Arabidopsis vacuolar sodium/proton antiporter gene in cotton improves photosynthetic performance under salt conditions and increases fiber yield in the field. Plant Cell Physiology 46:1848-1854

17. Iqbal M, Ashraf M (2007) Seed treatment with auxins modulates growth and ion partitioning in saltstressed wheat plants. Bot Gazette 49(7):1003-1015

18. Janas KM, Posmyk MM (2013) Melatonin, an underestimated natural substance with great potential for agricultural application. Acta Physiologiae Plantarum 35:3285-3292

19. Javid MG, Sorooshzadeh A, Moradi F, Sanavy SAMM, Allahdadi I(2011) The role of phytohormones in alleviating salt stress in crop plants. Australian Journal of Crop Science (Aust J Crop Sci) 32:726734

20. Jiang CQ, Cui QR, Feng K, Xu D, Li C, Zheng Q (2016) Melatonin improves antioxidant capacity and ion homeostasis and enhances salt tolerance in maize seedlings. Acta Physiol Plant 38:82

21. Kaya C, Ashraf M, Dikilitas M, Tuna AL (2013) Alleviation of salt stress-induced adverse effects on maize plants by exogenous application of indoleacetic acid (IAA) and inorganic nutrients - a field trial. Aust J Crop Sci 7:249-254

22. Kojima M, Sakakibara H(2012). Highly sensitive high-throughput profiling of six phytohormones using MS-probe modification and liquid chromatography-tandem mass spectrometry. Methods in Molecular Biology 918:151-164

23. Kosová K, Prášil IT, Pavel V, Petre D, Václav M, Kristýna F, Ondřej N, Veronika T, Jakub R, Bedřich P, Alena T, Alena G, Gabor G, Tibor J, Eva V, Pavla P, Radomíra V(2012). Complex phytohormone 
responses during the cold acclimation of two wheat cultivars differing in cold tolerance, winter samanta and spring Sandra. J Plant Physiol 169(6):567-576

24. Kostopoulou Z, Therios I, Roumeliotis E, Kanellis AK, Molassiotis A (2014) Melatonin combined with ascorbic acid provides salt adaptation in Citrus aurantium L. seedlings. Plant Physiology Biochemistry 86:155-165

25. Li J, Liu J, Zhu T, Zhao C, Li L, Chen M (2019) The role of melatonin in salt stress responses. International Journal of Molecular Sciences 20:1735

26. Liang D, Gao F, Ni ZY, Lin L (2018). Melatonin improves heat tolerance in kiwifruit seedlings through promoting antioxidant enzymatic activity and glutathione S-transferase transcription. Molecules 23:584

27. Liu CY, Wang P, Zhang DJ, Zou YN, Kuca K, Wu QS. (2018) Mycorrhiza-induced change in root hair growth is associated with IAA accumulation and expression of EXPs in trifoliate orange under two $P$ levels. Sci Horti 234:227-235

28. Liu J, Guo C, Chen ZL, He JD, Zou YN(2016) Mycorrhizal inoculation modulates root morphology and root phytohormone responses in trifoliate orange under drought stress. Emir J Food Agric 28:251-256

29. Lu C, Jiang G, Wang B, Kuang T (2003) Photosystem ii photochemistry and photosynthetic pigment composition in salt-adapted halophyte artimisia anethifolia grown under outdoor conditions. Journal of Plant Physiology 160(4):403-408

30. Mahmud S, Sharmin S, Chowdhury BLD, Hossain MA, Bhuiyan MJH(2016) Mitigation of salt stress in rice plant at germination stage by using methyl jasmonate. Asian J Med Biol Res 2:74-81

31. Meng JF, Xu TF, Wang ZZ, Fang YL, Xi ZM, Zhang ZW(2015) The ameliorative effects of exogenous melatonin on grape cuttings under water-deficient stress: antioxidant metabolites, leaf anatomy, and chloroplast morphology. J Pineal Res 57:200-212

32. Mimuro M, Akimoto S, Yamazaki I, Miyashita H, Miyachi S(1999) Fluorescence properties of chlorophyll d-dominating prokaryotic alga, acaryochloris marina: studies using time-resolved fluorescence spectroscopy on intact cells. Biochim Biophys Acta 1412:37-46

33. Park S, Back K (2012) Melatonin promotes seminal root elongation and root growth in transgenic rice after germination. Journal of Pineal Research (J Pineal Res) 53:385-389

34. Pill WG (1995) Low water potential and presowing germination treatments to improve seed quality, In: Basra A.S.,1995,Seed quality: Basic mechanisms and agricultural implications, The Haworth Press, Binghamton, NY, USA, pp:319-359

35. Schreiber U, Bilger W, Hormann H, Neubauer C (1998) Chlorophyll fluorescence as a diagnostic tool: basics and some aspects of practical relevance. Cambridge: Cambridge University Press, 320-336

36. Shibata S, Satou F, Kimura H, Oyabu T (2012) The relationship between chlorophyll fluorescence parameter ( $F v / F m)$ and frequency component of plant bioelectric potential in spraying chemical herbicides. IEEJ Transactions on Sensors and Micromachines 132:154-158 
37. Sowmyalakshmi S, Han L, Pierre D, Smith DL (2015) Computed tomography scanning can monitor the effects of soil medium on root system development: an example of salt stress in corn. Frontiers in Plant Science 6:256

38. Stassinos PM, Rossi M, Borromeo I, Capo C, Forni C (2021) Amelioration of salt stress tolerance in rapeseed (brassica napus) cultivars by seed inoculation with arthrobacter globiformis. Plant Biosystems 5:1-12

39. Stassinos PM, Rossi M, Borromeo I, Capo C, Forni C (2021) Amelioration of salt stress tolerance in rapeseed (Brassica napus) cultivars by seed inoculation with Arthrobacter globiformis. Plant Biosystems 5:1-12

40. Sun S, Wen D, Yang W, Meng Q, Gong B (2020) Overexpression of caffeic acid O-methy/transferase 1 (COMT1) increases melatonin level and salt stress tolerance in tomato plant. Journal of Plant Growth Regulation 39(3): 1-15

41. Tan DX, Manchester LC, Reiter RJ, Qi WB, Karbownik M, Calvo JR(2000) Significance of melatonin in antioxidative defense system:Reactions and products,Biological Signals and Receptors 9:137-159

42. Tan DX, Hardeland R, Manchester LC, Ahmet K, Ma S, Sergio RC, Reiter RJ (2012) Functional roles of melatonin in plants, and perspectives in nutritional and agricultural science. J Exp Bot 63(2):577-597

43. Tietz S, Hall CC, Cruz JA, Kramer DM (2017) NPQ(T): a chlorophyll fluorescence parameter for rapid estimation and imaging of non-photochemical quenching of excitons in photosystem-Il-associated antenna complexes. Plant Cell Environ 40(8):1243-1255

44. Tiryaki I, Keles H(2012) Reversal of the inhibitory effect oflight and high temperature on germination of Phacelia tanacetifolia seeds by melatonin, Journal of Pineal Research 52(3):332-339

45. Wang $L Y$, Liu JL, Wang WX, Sun Y(2016) Exogenous melatonin improves growth and photosynthetic capacity of cucumber under salinity-induced stress. Photosynthetica 54:19-27

46. Wang X, Zhang D, Qi Q, Tong S, An Y, Lu X, Liu Y (2019) The restoration feasibility of degraded carex tussock in soda-salinization area in arid region. Ecological Indicators 98:131-136

47. Wei W, Li QT, Chu YN, Reiter RJ, Yu XM, Zhu DH, Zhang WK, Ma B, Lin Q, Zhang JS (2015) Melatonin enhances plant growth and abiotic stress tolerance in soybean plants. J Exp Bot 3:695-707

48. Wu QS, Zou YN, HeXH(2010b) Contributions of arbuscular mycorrhizal fungi to growth, photosynthesis, root morphology and ionic balance of citrus seedlings under salt stress. Acta Physiologia Plantarum 32:297-304

49. Wu QS, Zou YN, Liu W, Ye XF, Zai HF, Zhao LJ (2010a) Alleviation of salt stress in citrus seedlings inoculated with mycorrhiza: changes in leaf antioxidant defense systems. Plant, Soil and Environment 56:470-475

50. Wu QS, Zou YN (2009) Arbuscular mycorrhizal symbiosis improves growth and root nutrient status of citrus subjected to salt stress. ScienceAsia 35:388-391

51. Wu QS, Zou YN(2013) Mycorrhizal symbiosis alters root H+ effluxes and root system architecture of trifoliate orange seedlings under salt stress. Journal of Animal and Plant Sciences 23:143-148 
52. Ye J, Wang SW, Deng XP, Yin LN, Xiong BL, Wang XY (2016). Melatonin increased maize (Zea mays L.) seedling drought tolerance by alleviating drought-induced photosynthetic inhibition and oxidative damage. Acta Physiologiae Plantarum 38:48

53. Zhang DJ, Xia RX, Cao X, Shu B, Chen CL (2013) Root hair development of Poncirus trifoliata grown in different growth cultures and treated with 3-indolebutyric acid and ethephon. Sci Horti 160:3893970

54. Zhang DJ, Xia RX, Cao X (2016) Ethylene modulates root hair development in trifoliate orange through auxin-signaling pathway. Sci Horti 213:252-259 0

55. Zhang DJ, Yang YJ, Liu CY, Zhang F, Hu W, Gong SB, Wu QS (2018) Auxin modulates root hair growth through its signaling pathway in citrus. Sci Horti 236:73-78 0

56. Zhang DJ, Liu CY, Yang YJ, Wu QS, Li YY (2019) Plant root hair growth in response to hormones. Notulae Botanicae Horti Agrobotanici Cluj-Napoca 47:278-281 0

57. Zhang N, Zhao B, Zhang HJ, Weeda S, Yang C(2003) Melation promoteswater-stress tolerance,lateral root for mation, and seed germination in cucumber (Cucumis sativus L.). J Pineal Res 54:15-23

58. Zhang YC, Wang P, Wu QH, Zou YN, Bao Q, Wu QS (2017) Arbuscular mycorrhizas improve plant growth and soil structure in trifoliate orange under salt stress. Archives of Agronomy and Soil Science 63:491-500

59. Zhang N, Jiang Q, Dian-Bo LI, Cai LT, Zhang HJ, Si WJ, Fan XF, Guo YD(2014) Effect of exogenous melatonin on germination of Pennisetum alopecuroides under $\mathrm{NaCl}$ stress. Journal of China Agricultural University 19:54-60 (In Chinese)

60. Zhou Z, Li Z, Zhang Z, You L, Cui X (2021) Treatment of the saline-alkali soil with acidic corn stalk biochar and its effect on the sorghum yield in western songnen plain. Sci Total Environ 797:149190 